УДК $316.62: 324$

https://doi.org/10.34142/24130060.2019.17.1.14

\title{
КОНЦЕПТУАЛЬНІ ОСНОВИ ЕЛЕКТОРАЛЬНОЇ КУЛЬТУРИ
}

\section{І.О. Поліщук}

Національний юридичний університет імені Ярослава Мудрого

Стаття присвячена розгляду поняття та концептуального базису електоральної культури. Аналізуючи різноманітні наукові моделі вказаної категорії, автор пропонує свою версію конщепиії електоральної культури. При иььоу основна увага приділяється дослідженню реалій транзитивних суспільств. Робиться висновок, щуо у транзитивних соиіумах електоральна культура виступає необхідним індикатором, який дозволяє зрозуміти стан розвитку їхньої політичної культури у певний історичний період. Обмеження понятійного поля політичної культури сферою електоральної культури дозволяє виокремити пласт «живої》 участі в політиці громадян, які лише опановують різні форми демократичної участі у політичному прочесі перехідних режсиів.

Ключові слова: політичні вибори, електоральна культура, транзитивне суспільство, демократія.

\section{КОНЦЕПТУАЛЬНЫЕ ОСНОВЫ ЭЛЕКТОРАЛЬНОЙ КУЛЬТУРЫ}

\section{И.А. Полищук}

Статья посвящена рассмотрению понятия $u$ конщептуального базиса электоральной культуры. Анализируя различные научные модели указанной категории, автор предлагает свою версию концепции электоральной культуры. При этом основное внимание уделяется исследованию реалий транзитивных обществ. Делается вывод, что в транзитивных социумах электоральная культура выступает необходимым индикатором, который позволяет понять состояние развития их политической культуры в определенный исторический период. Ограничение понятийного поля политической культуры сферой электоральной культуры позволяет выделить пласт «живой» участия в политике граждан, которые только овладевают различными формами демократического участия в политическом прочессе переходных режимов.

Ключевые слова: политические выборы, электоральная культура, транзитивное общество, демократия.

\section{CONCEPTUAL BASIS OF ELECTORAL CULTURE}

\section{Polischuk}

The article is devoted to the consideration of the concept and conceptual basis of electoral culture. Analyzing various scientific models of this category, the author presents his version of the concept of electoral culture. At the same time, the main attention is paid to the study of the realities of transitive societies. The main purpose of this article is to carry out demarcation and determine the subordination between the categories «political» and «electoral» culture. The study of the electoral culture of transitional societies is evident in the following circumstances. The phenomenon of a transitive society has long been at the center of the attention of researchers. To date, dozens or even hundreds of different scientific theories have 
been developed that are trying to describe and explain the complex phenomenon mentioned. The people as the only source of power, voting for representatives of certain political forces, determine the personal composition of the political elite and prefer a certain program of development of society. The election is the only possible and only recognized procedure in the civilized world for legitimizing state power and is a universal criterion for determining progress in the development of one or another political system. It is concluded that in electoral circles in electoral circles, electoral culture is an indispensable indicator that allows us to understand the state of development of their political culture in a certain historical period. The restriction of the conceptual field of political culture by the sphere of electoral culture makes it possible to isolate the stratum of «living» participation in the policy of citizens who only master various forms of democratic participation in the political process of transitional regimes.

Key words: political elections, electoral culture, transitive society, democracy.

Постановка проблеми. Вивчення електоральної культури перехідних суспільств має наочний характер через наступні обставини. Феномен транзитивного суспільства вже тривалий час знаходиться у центрі уваги дослідників. На сьогодні розроблені десятки, а то й сотні різноманітних наукових теорій, які намагаються описати та пояснити згаданий складний феномен. Проте на часі варто ставити питання про засоби впливу на транзитивні соціуми 3 метою досягнення якісних трансформацій. В цьому контексті демократичний ідеал виступає мобілізуючим орієнтиром для небайдужих політичних акторів та експертів, які займають активну громадянську позицію. Висока конкурентоспроможність країн консолідованої демократії, їхній вирішальний вплив на світовий політичний процес змушують розглядати їх у якості певного еталону розвитку та вибудовувати стратегії реформування власної політичної системи 3 урахуванням та використанням передового іноземного досвіду.

Вкрай важливим завданням у цьому зв’язку виступає проблема пошуку необхідних системних індикаторів, зміна якості яких означатиме реальну, а не декларовану демократизацію політичного процесу у перехідних суспільствах. Здавалося, що такий індикатор вже давно віднайдено американськими класиками політичної науки Г. Алмондом та С. Вербою. Йдеться про категорію політичної культури тієї чи іншої країни. I дійсно, концепція політичної культури є доволі плодотворною для вивчення процесів у стабільних суспільствах. Первісною перевагою концепції політичної 
культури виступав iї інтегративний характер. Вона охопила низку явищ політичного життя, які розглядалися ізольовано-історично: детерміновані цінності та норми, психологія нації, кросскультурні взаємодії i т. ін. Концепції політичної свідомості не змогли інтегрувати ці явища. Зазначимо ще одну важливу особливість концепції політичної культури - вона дозволяє зрозуміти специфіку національного політичного життя через аналіз традицій, історичного досвіду народу, своєрідної системи цінностей. Г. Алмонд та С. Верба висловили думку, що політична культура обмежується сферою свідомості та є сукупністю психічних станів індивіда, які виявляються на трьох рівнях: когнітивному (пізнання), афективному (емоції) та оціночному (судження). Тобто засновники концепції політичної культури зводили іiі до сукупності сталих політичних уявлень, переконань, почуттів та оцінок. Вони наголошували на суб'єктивних рисах політичної культури і не включали до неї політичну діяльність. Сформульоване Г. Алмондом і С. Вербою (1963, р. 498) визначення політичної культури вважається класичним. А. Кардінер та С. Вайт на противагу згаданим вченим навпаки акцентували увагу на об’єктивному аспекті цього явища, а саме на політичній діяльності та поведінці носіїв політичної культури.

Проте великий змістовний обсяг та ідейна спрямованість поняття «політична культура», яке 3 моменту впровадження у науковий обіг на сьогодні налічує понад 300 дефініцій, робить його застосування для транзитивних суспільств проблематичним. По-перше, когнітивний рівень, тобто рівень пізнання політики опиняється у кризі через ухід від застарілих практик політики та мляве й болісне народження нових практик. По-друге, емоційний рівень виявляється заздалегідь визначеним, адже переживання соціально-економічної та духовної кризи завжди супроводжується негативними емоціями з превалюванням латентного (а іноді й легального) протесту проти владного курсу «реформаторів». По-третє, оціночний аспект теж виявляється заданим заздалегідь, адже громадяни, що позбавлені нових ідеологічних орієнтирів, репродукують маргінальні оцінки політики та 
політиків. Щодо діяльнісного підходу А. Кардінера та С. Вайта, то тут все ще більш проблематично. Справа в тому, що «мертва» чи ритуальна участь у політиці переважної частини населення в авторитарних та тоталітарних режимах інерційно успадковується ними й на початку переходу до демократії. Громадяни у транзитивних суспільствах втрачають «механічну», неусвідомлену участь у політичному процесі, але ще не здобувають нову, усвідомлену участь. Вони лише вчаться опановувати нові політичні практики та відносини. Де ж у перехідних суспільствах ми можемо спостерігати реальну участь громадян у політиці? Головним чином, у виборчому процесі. Саме на конкурентних виборах й відбувається реальне навчання участі громадян у «живій» політиці.

Аналіз актуальних досліджень. Однією з перших робіт вітчизняних дослідників, яка повністю була присвячена проблемі електоральної культури було наукове дослідження О. В. Князєвої (1996) «Електоральна поведінка як соціокультурне явище». Використовуючи соціологічний підхід, автор визначає основні об’єктивні та суб'єктивні фактори, які впливають на поведінку виборців, подає типологію електоральної поведінки тощо.

Натомість чи не єдиною фундаментальною працею, яка безпосередньо присвячена всебічному вивченню феномену електоральної культури, $\epsilon$ дисертація на здобуття вченого ступеня доктора політичних наук «Електоральна культура: політологічний аналіз» російського дослідника I. М. Гомерова (1995) (м. Новосибірськ). У цій роботі міститься цікава версія осмислення суті, побудови, способів функціонування електоральної культури, ïi місця та ролі в структурі політичної культури та виборчому процесі. I. М. Гомеров в рамках підходу системно-архітектурного моделювання запропонував робоче визначення та власну концепцію електоральної культури, впровадив поняття «електоральні орієнтації», узагальнив існуючі в науковій літературі засоби моделювання політичних виборів, електорального середовища, виокремив психологічні, економічні, політичні, духовні фактори, які впливають на вибір електорату. І. М. Гомеров 
також виявив найбільш характерні для сучасної електоральної культури іміджі претендентів на виборні посади, життєвий цикл даних конструктів, проаналізував базові моделі просування кандидатів на політичному ринку, розробив відповідні рекомендації щодо проектування, стратегічного планування електоральних кампаній в транзитивних (перехідних) суспільствах. Дослідник розглядає електоральну культуру як систему, яка моделює іншу систему - політичні вибори. При цьому він розуміє під моделюванням «певну функцію однієї системи (електоральної культури) по відношенню до іншої системи (політичних виборів). Суть цієї функції полягає в тому, що одна система (електоральна культура) представляє (заміняє, заступає) іншу систему (політичні вибори) таким чином, що між представляючою (заміняючою, заступаючою) системою та системою, яку представляють (заміняють, заступають) - політичними виборами встановлюється подібність (відповідність) за низкою найбільш істотних ознак» (Гомеров, 1995, с. 25).

Грунтовно займається вивченням електоральної культури російських громадян вчений Гарвардського університету В.Я. Гельман. В лекції «Політична культура, масова участь та електоральна поведінка. Росія в порівняльній перспективі» вчений розкриває, як чином політична культура чинить вплив на діяльність росіян в політичному процесі, їхній електоральний вибір та активність у виборчих кампаніях. Трансформаційні процеси в електоральній культурі росіян розкриваються в його спільній роботі з В. П. Слезаровим (2000) «Установчі вибори» в контексті російської трансформації».

У вітчизняному суспільствознавстві цікавій для нас науковій проблемі присвячена дисертація «Електоральна культура населення України в умовах трансформації суспільства» Б. Ідрісова (2006). В цій роботі досліджується становлення електоральної культури громадян України. Автор робить висновок, що електоральна культура суспільства, що трансформується, є динамічною єдністю знання, розуміння суті, змісту демократичних виборів 
усіма учасниками виборчого процесу, реально відображає стан засвоєних зразків і норм поведінки.

Слід наголосити, що у науковому обігу на сьогодні вживаються різні словосполучення для позначення феномену «електоральної культури»: «культура політичних виборів», «культура виборців», «культура виборчого процесу» та ін. Всі ці відтінки категорії «електоральна культура» мають свою змістовну специфіку. Наприклад, «культура виборчого процесу» передбачає широке трактування, охоплення всіх учасників даного процесу (включаючи не тільки громадян, що голосують, але й активних суб'єктів виборчого процесу: партій, блоків, їх лідерів, спостерігачів, членів виборчих комісій тощо). Поняття «електоральна культура» налаштовує на обмеження кола іiі носіїв лише виборцями, які голосують. Поняття «культура політичних виборів» за своїм змістом начебто є тотожною поняттю «культура виборчого процесу». Проте, якщо вдуматися в справжню суть названих категорій, то стає наочною їхня принципова ідентичність, адже в кінцевому результаті всі учасники електорального процесу виступають в ролі виборців. Скажімо, кандидати в президенти теж приходять на виборчі дільниці і голосують, не важко здогадатися за кого. Акт голосування об’єднує й інших учасників електоральної кампанії. Тому цілком виправданим є вживати названі поняття - словосполучення як синоніми.

Саме електоральний процес за умов проведення вільних, прозорих, чесних, конкурентних виборів отримує детермінуючого значення щодо політичного розвитку транзитивних режимів. Народ як єдине джерело влади, голосуючи за представників певних політичних сил, визначає персональний склад політичної еліти та віддає перевагу певній програмі розвитку суспільства. Вибори є єдино можливою та єдино визнаною в цивілізованому світі процедурою легітимізації державної влади і є універсальним критерієм визначення прогресу в розвитку того чи іншого політичного ладу. 
Звідси основною метою даної статті є проведення демаркації та визначення субординації між категоріями «політична» та «електоральна» культура.

Виклад основного матеріалу. Дослідження електоральної культури або культури політичних виборів були започатковані у США. Американський політолог П. Лазарсфельд здійснив одне 3 перших розгорнутих досліджень факторів, що впливають на електоральний вибір громадян. В центрі його уваги була проблема впливу засобів масової інформації (насамперед, радіо та телебачення) на електоральну поведінку американців. У підсумку були виявлені цікаві закономірності сприйняття населенням 3МІ. П. Лазарсфельд відкрив закон селективності сприйняття виборцями засобів масової комунікації. Його суть в тому, що середній виборець приділяє увагу тільки тим інформаційним матеріалам, які відповідають його первісним політичним поглядам. Також було встановлено, що люди, які є членами однієї соціальної групи, голосують майже завжди ідентично. Крім того, П. Лазарсфельд відкрив закон «лідерів думок». Його зміст полягає в тому, що масовий виборець сприймає політичну інформацію набагато краще, якщо вона розповсюджується не просто конкретними 3МI, а iï джерелом виступає популярна особистість - т.зв. «лідер думок». Тож саме «лідери думок» стають вельми привабливими для політичних акторів ретрансляторами необхідної політичної пропаганди, причому як прямої, так i непрямої. На базі закону «лідерів думок» виникає ціла концепція «двоетапної комунікації», першоавторство якої належить П. Лазарсфельду та його однодумцям Б. Берельсону, Г. Годе та Е. Кацу (1968).

Дж. Клапер виокремив систему факторів-посередників, які визначають ефект масової комунікації. До них відносяться: готовність виборця сприйняти необхідну інформацію, міжособистісний характер розповсюдження інформації, належність людини до соціальної групи 3 іi нормами, вплив лідерів думок на розповсюдження та оцінку інформації. Ці 
фактори спричиняють повноту засвоєння конкретним індивідом політичної інформації (1960).

Реалії виборчого процесу в посткомуністичних суспільствах доволі точно описує модернізована модель «соціальних розколів», яку розробив Г. Кітчельт. Вчений на основі дослідження політичних систем країн нових демократій Центральної та Східної Європи запропонував свою класифікацію розколів в політичному просторі даних країн, які мають вирішальне значення для їх електорального процесу. До числа найбільш глибоких політичних розколів він відніс наступні: 1) конфлікт перерозподілу як прояв класичного економічного розколу, що виявляється в політичному розмежування на лівих і правих; 2) конфлікт політичних принципів як протиставлення настанов 3 приводу характеру й контролю суспільного управління: принципи колективності й авторитаризму, індивідуалізму і лібералізму; 3) конфлікт громадянськості, пов'язаний із протиставленням універсального розуміння громадянськості на основі етнічних, релігійних, лінгвістичних та інших факторів (Kitchelt, 1997). На мою думку, дана модель має певну цінність, адже дозволяє простежити основні лініі розколів у суспільствах, що трансформуються, хоча й не в повному обсязі розкриває дію суб'єктивних, ірраціональних факторів поведінки електорату в нових демократіях.

Останнім часом можна говорити про формування ще однієї, технологічної моделі голосування виборців. Серед фахівців-політологів Росії (Г. Павловський, С. Кара-Мурза, М. Кошелюк та ін.) і України (Д. Видрін) розповсюджена думка, що підступні маніпулятивні виборчі технології, які зовсім необов'язково мають узгоджуватися з законами держави та мораллю, приносять успіх їх реалізаторам у будь-якому випадку та за будь-яку ціну. За умов інформаційного суспільства на зміну політичним партіям як суб'єктам політичної боротьби поступово приходять невеличкі групи професіоналів, які здатні до гнучкого реагування на політичну кон'юнктуру, оперативного впливу на свідомість виборців. Вчені все більше говорять про виникнення партій принципово нового типу - «технологічних» партій, певних 
«електоральних машин», діяльність яких грунтується в основному на маркетингових технологіях, що інтенсивно розвиваються передусім на Заході та набувають обертів і в країнах пострадянського простору.

Проте є підстави стверджувати, що не слід перебільшувати масштаб дії цієї концепції. Більшість висококваліфікованих дослідників одноголосно вважають, що межа короткотермінової маніпулятивної мобілізації електорату під час виборної кампанії становить 10-20\% громадян 3 правом голосу. Як тут не згадати відомий вислів американського президента А. Лінкольна про те, що можна достатньо довго дурити небагатьох людей, можна недовго дурити багатьох, але не можна завжди дурити всіх. Звичайно, це зауваження має сенс лише за умов демократичного режиму. Звідси випливає висновок, що лише демократія 3 конкурентними виборами може дати розгорнуті уявлення про особливості політичної (електоральної) культури громадян.

У транзитивних суспільствах кожні нові вибори задають чи корегують вектор розвитку цих суспільств, тому зазвичай мають для них «доленосне» значення. Ще раз варто наголосити, що в соціумах з розвинутою демократією громадяни мають широке коло можливостей брати участь в політичному житті своєї країни або, бодай, впливати на ухвалення важливих політичних рішень. В транзитивних суспільствах реальні можливості громадян стосовно докладання політичних зусиль обмежуються в основному електоральними функціями. Це обумовлює зростаючу питому вагу електоральної культури взагалі в структурі політичної культури націй, що переживають період трансформації, адже вона починає виступати як найважливіший показовий елемент їхньої політичної культури як такої. Звідси плодотворним $є$ виділення в окрему, самостійну категорію поняття «електоральна культура».

Національна електоральна культура $є$ глобальним регулятором поведінки суб’єктів виборчого процесу в тій чи іншій країні. Їй притаманні такі параметри: типове ставлення населення до влади, виборів як процедури народного волевиявлення, рівень довіри владним інституціям, специфіка національного виборчого законодавства, ідеологічні орієнтації, мотивація та 
голосування, ставлення до опонентів, електоральна активність, характер домінуючих виборчих технологій, типові засоби політичної боротьби в ході проведення виборчих кампаній тощо. Все це визначається не тільки поточною ситуацією, а й політичними традиціями конкретного народу. Рівень консолідованості та централізованості електоральної культури є значно нижчим у суспільстві з патронатно-клієнталістськими відносинами.

На мій погляд, електоральна культура (культура політичних виборів) - це сукупність типових, відносно сталих знань, уявлень, настанов, переконань, цінностей, символів, орієнтацій, навичок, зразків поведінки, які проявляються у виборчому процесі та транслюються від генерації до генерації певної нації, але мають істотний трансформаційний потенціал та проступають в діяльності суб'єктів електорального процесу та у функціонуванні демократичних інститутів (Поліщук, 2005).

Електоральна культура виявляється у сприйнятті та ставленні до виборчого законодавства, партій, кандидатів, виборчих комісій, у самоідентифікації себе як прихильника тієї чи тієї партії, політичної сили, у реалізації свого права на голос. Іншими словами, електоральна культура - це відносно стійка система знань, оцінок і норм електоральної поведінки й електоральних відносин, виборчого процесу в цілому, колективна пам'ять людей про виборчі процеси. Можна сказати, що електоральна культура - це своєрідна «активна» частина політичної культури, особливість якої полягає ще й у iï динаміці та ритмі (яскраво це проявляється в посткомуністичних країнах, зокрема в Україні та Росії, де виборчі кампанії починаються тільки за рік-півтора до дня голосування, у той час як на Заході зазвичай проводять кампанію від одного дня голосування до іншого відповідно до виразу «Наступна кампанія розпочинається наступного дня після оголошення результатів попередньої»). Тож, електоральна культура тривалий час перебуває в латентному вигляді і проявляється та актуалізується тільки в періоди виборчих кампаній. Електоральна культура несе зміну цих елементів, адже вона і є їхнім джерелом. Прикметно, що сучасні виборчі кампанії часто 
бувають важко прогнозованими. У ході їх здійснення за допомогою ЗМІ конструюється нова символічна реальність. Як відомо, електоральна кампанія складається 3 декількох обов’язкових етапів незалежно від ії рівня та місця проведення. Ці етапи демонструє наступна схема.

\section{Схема 1. Електоральна кампанія (основні етапи)}
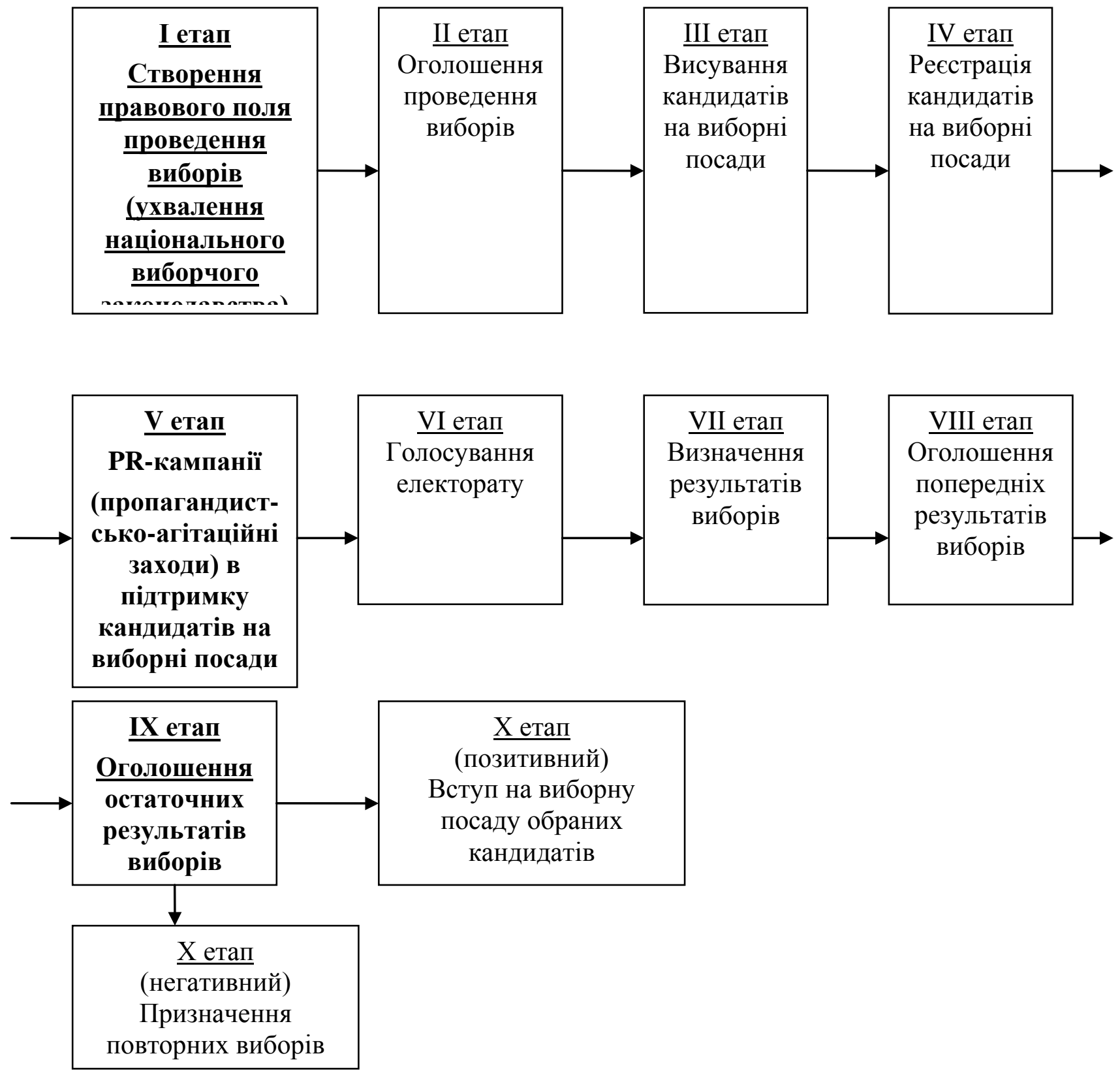

3 одного боку, перший, п'ятий та дев'ятий етапи електоральної кампанії є, певними індикаторами національної електоральної культури, а 3 іншого боку, є процесуальними періодами, характерні особливості яких 
спричинені оригінальними якостями виборчої культури тієї чи іншої нації, тобто їх розвиток детермінується національним політико-культурним фактором. Це саме стосується й десятого етапу, особливо в його негативному варіанті, коли через різноманітні негаразди призначаються повторні вибори.

Як бачимо, саме електоральна культура є базовим фактором поведінки виборців, адже вона вбирає в себе всі найважливіші внутрішньопсихологічні чинники індивіда.

Висновки і перспективи подальших досліджень. Таким чином, у транзитивних суспільствах саме електоральна культура виступає тим необхідним індикатором, що дозволяє зрозуміти стан розвитку їхньої політичної культури у певний історичний період. Обмеження понятійного поля політичної культури сферою електоральної культури дозволяє виокремити пласт «живої» участі в політиці громадян, які лише навчаються, опановують різні форми демократичної участі у політичному процесі перехідних режимів. Категоріальне звуження з розмитої натепер концепції політичної культури до концепту електоральної культури у перспективі дозволяє більш точно визначити предмет впливу, «больову точку» політичної еволюції перехідних країн 3 метою розроблення ефективних технологій впливу на розвиток політичної ментальності населення країн 3 транзитивними режимами у бік іiі реальної демократизації. Тому подальше розроблення концепції електоральної культури становить нагальне завдання для вітчизняних вчених-політологів.

\section{ЛІТЕРАТУРА}

1. Гельман, В.Я. и Елезаров, В.П., 2000. «Учредительные выборы» в контексте российской трансформации. В: В.Я. Гельман, Г.В. Голосов и Е.Ю. Мелешкина, ред. Первый электоральный цикл в России (1993-1996). Москва. с. 13-43.

2. Гомеров, И.Н., 1995. Электоральная культура: политологический анализ. Кандидат наук. Автореферат. Московский государственный університет.

3. Князєва, О.В., 1996. Електоральна поведінка як соџіокультурне явище. Кандидат наук. Автореферат. Харківський національний університет імені В.Н. Каразіна.

4. Ідрісов, Б., 2006. Електоральна культура населення Украӥни в умовах трансформачіі cуспільства. Кандидат наук. Автореферат. Ін-т соціології НАН України, Київ. 
5. Поліщук, I.О., 2005. Поняття «електоральна культура». В: Проблеми формування електоральної культури населення: 3б. наук. ст. (за матеріалами XVII Харк. політол. читань). Харків. с. 71-72.

6. Almond, G. and Verba, S. 1963. The Civic Culture. Political Attitudes and Democracy in Five Nations. Princeton, N.J.

7. Kitchelt, H., 1997. European Party Systems: Continuity and Change. In: M. Rhodes, P. Heywood and V. Wright, eds. Developments in West European Politics. London, p. 131-150.

8. Klapper, J. T. 1960. The Effects of Mass Communication. Glencoe (Illinois): The Free Press.

9. Lasarsfeld, P.F., Berelson, B. and Gaudet, H. 1968. The Peoples Choice. How the Voter Makes up his Mind in a Presidential Campaign. New York.; London: Columbia univ. press.

\section{Інформація про автора}

Поліщук Ігор Олексійович - доктор політичних наук, професор, професор кафедри соціології та політології Національного юридичного університету імені Ярослава Мудрого (м. Харків); e-mail: i_polischuk@ukr.net; ORCID: http://orcid.org/0000-0001-6864-4425.

Стаття надійшла до редакції: 16.01.2019 р. $\quad$ Прийнята до друку: 31.01.2019 p. 